ELORE (ISSN 1456-3010), vol. $18-2 / 2011$.

Julkaisija: Suomen Kansantietouden Tutkijain Seura ry.

[http://www.elore.fi/arkisto/2_11/kauhanen.pdf]

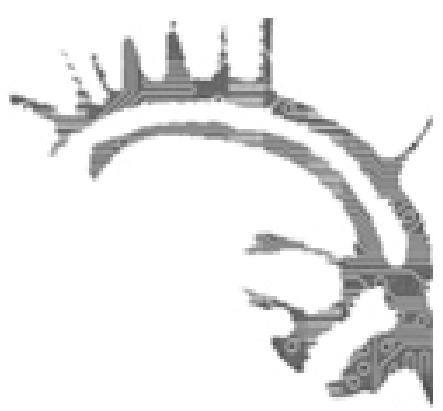

\title{
HaAstattelut arkeologiassa
}

\author{
$\underline{\text { Riku Kauhanen }}$
}

Vaikka suurin osa arkeologian tutkimusaineistoista hankitaankin lastalla ja lapiolla kaivamalla ja tutkittavat kohteet löydetään maastossa tehdyissä inventoinneissa, on myös ihmisiltä kysymällä saatu tieto tavalla tai toisella olennaista arkeologeille. Paikallisten informanttien käytön korostuminen ja vastaavasti vähättely vaihtelee. Mutta onko heiltä muutakin kysyttävää kuin "Oletteko nähneet kvartsi-iskoksia näillä main?" Haastatteluilla hankittavien tietojen historia on Suomessa yllättävän pitkä, ja muutaman viime vuosikymmenen aikana tehdyissä tutkimuksissa on yhä useammin turvauduttu kyselytietoon paitsi uusien tietojen, myös tulkintojen saamiseksi tutkimuskohteesta. Samalla tutkimuskohteeseen enemmän tai vähemmän liittyvien ihmisten käsityksiä arkeologiasta on saatu muokattua - ja päinvastoin.

\section{KIHLAKUNTAKERTOMUSTEN HAASTAMAA}

Vuosina 1877-1902 Suomen Muinaismuistoyhdistys julkaisi 23 kpl kihlakuntakertomuksia nimellä Luetteloja Suomen muinaisjäännökesistä. Näihin on lueteltu kihlakunnittain alueiden tunnettuja kiinteitä muinaisjäännökset ja irtolöytöjä. Osa kihlakuntakertomuksista, esimerkiksi Kymen kihlakunnan, on Museoviraston arkeologian osaston arkistossa julkaisemattomina käsikirjoituksina. Kihlakuntakertomukset laadittiin nimestä "Luetteloja Suomen muinaisjäännöksistä” huolimatta monissa tapauksissa hyvin holistisesti, ja paikallisilta informanteilta kerättiin tietoja myös asutustarinoista, taikauskosta ja sotamuistoista. Myös muista aiheista kuten "olennoista ja käsitteistä joille omistettiin yliluonnollinen voima" (kts. esim. Pelkonen 1902, 203.), vähemmistöistä kuten romaneista eli mustalaisista (Takala 1896, 229) kerättiin tietoja, tai muistiin merkittiin vaikkapa Pietarsaaren Kihlakuntakertomuksessa lueteltuja "Tarinoita Jättiläisistä y. m.” (Takala 1896, 194). 


\section{Riku Kauhanen: Haastattelut arkeologiassa}

Kihlakuntakertomusten laatijoiden biografiat eivät käy ilmi teoksista, todennäköisesti he ovat taustaltaan apurahan saaneita ylioppilaita, tai kokoajat käyttivät ylioppilaita kenttätöissä. Kertomusten esipuheessa kiitetään useasti "hyväntahtoisia kansalaisia, jotka tavalla tai toisella ovat minua matkoillani ja tätä kertomusta valmistaessani tiedonannoilla auttaneet" (esim. Takala 1896, 4). Toisaalta Kymin kihlakuntakertomusten käsikirjoituksessa luetteloija A. R. Blomqvist syyttää keruunsa huonoista tuloksista paitsi omaa nuoruuttaan ja kokemattomuuttaan, myös "rahvaan välinpitämättömyyttä” muinaisjäännöksistä. "Tapahtui nimittäin väliin, ettei talon isäntä joka ikänsä oli asunut samalla paikalla, tietänyt tiluksillaan löytyvistä muinaisjäännöksistä, joista sitte naapureiden avulla sain tiedon" (Blomqvist: esipuhe). Kymin kihlakunnassa haittasi kivikauden esineistön, "vanhojen työaseiden", keruuta myös taikausko, tällaisia esineitä nimittäin pidettiin tunnetusti ukonnuolina ${ }^{1}$, ja näin ollen tehokkaina taikakaluina. Pernajan pitäjästä tiedetään luetella useitakin ukonvaajalöytöjä, ja ihmiset olivat niistä tietoisia vaikka eivät olisi niitä eläessään nähneetkään (Pakkala 1902, 24-26) Hollolan kihlakuntakertomusten kerääjä Väinö Wallin tutkii näitä havaintoja huomattavasti syvemmin. Hän tunnistaa "ukonvaajoihin" liittyvän taikauskon ja ihmiset, joilta näitä esineitä tapaa maagisessa käytössä. Wallin huomasi myös joidenkin keräävän tai tallettavan kivikautista esineistöä "vanhasta tavasta" tai "asian ymmärtäväisyyden vuoksi" (Wallin 1982, 23-24). Wallin selittää näillä seikoilla sitä, miksi niin vähän esineistöä saadaan museoihin, vaikka näennäisesti keräiltävää on runsaasti. Kiinnostavaa on että Wallin tulee - osaksi tietämättään - tunnistaneeksi useita eri suhtautumistapoja esihistorialliseen esineistöön.

Paikallisten informanttien käyttö on ollut olennaista kihlakuntakertomusten laatijoille. Vaikka yleensä viitataankin "kansaan" tai informanteista puhutaan passiivissa, mainitaan pariinkin otteeseen pääsyn muinaisjäännökselle estyneen, koska opas ei päässyt paikalle tai kieltäytyi auttamasta. Esimerkiksi Pietarsaaren kihlakuntakertomusten laatija Esa Takalaa "myöhäinen ilta ja oppaan kiiruhtaminen" estivät tutkimasta muutamia kivilatomuksia (Takala 1896,118). Samoin muinaistutkijalta jäi näyttämättä toteen eräällä kankaalla sijaitsevan kiukaan olemassaolo. "Toiset kumminkin väittivät sitä valheeksi, eivätkä ne pojat, jotka siitä puhuivat, ottaneet opastaakseen paikalle" (Takala 1896, 75).

Paikallisille esitetyissä kysymyksissä oli myös aiheittaisia painopisteitä. Sortavalan kihlakuntakertomuksen laatija oli professori Aspelinin pyynnöstä kuulustellut uutterasti lappalaisiin liittyvistä entisistä olopaikoista. Vastauksena oli muutama Lappiniminen paikka ja mainintoihin lappalaisista reagoitiin tavallisesti ihmettelemällä "Niin, sitä hiien väkeäkö?" tai "Niitä väinämöisiäkö tarkoitatte?” (Killinen 1889, 38). Tässä yhteydessä tunnistettiin emic-etic-tasot, ulkopuolisten tutkijoiden ja tutkittavien eri käsitykset samasta asiasta.

Kihlakuntakertomuksista löytää myös yhden kuvauksen itse haastattelutilanteesta ja -tekniikasta. Sortavalan kihlakuntakertomusten laatija Kust. Killinen luettelee leikkimielisesti muinaisjäännöksiin myös ukko Borissan eli Ontrei Vannisen, kappaleella "Runolaulaja". Killinen yritti haastatella tätä yhdeksänkymppistä miestä paikkakunnan muinaisjäännöksistä, mutta tämä vaikeni. Killinen kuvaa kyselytekniikkaansa "...ja kyselin häneltä yhtä sun toista seudun muinaisuudesta, ei hän vastannut juuri mitään, 


\section{Riku Kauhanen: Haastattelut arkeologiassa}

vaikken minä suinkaan tehnyt väkirynnäkköä, vaan johdattelin puhetta vähitellen asiaan”. Lopulta Killisen otettua esille 50-pennisen ja laskettua tämän pöydälle ukon eteen tämä kysyi heti, mitä kyselijä oikeastaan halusikaan kuulla. Killinen saikin laulua pyydettyään kuulla runoja ja useita loitsuja (Killinen 1889, 67-68).

\section{JÄTEMENNEISYYS}

Arkeologian suhdetta muihin kulttuurientutkimuksen ja sosiologian aloihin on leimannut alan tutkimuskohteiden ja aineistojen kvantitatiivisuus suhteessa esimerkiksi etnografian, antropologian tai sosiologian lähteiden kvalitatiivisuuteen, kuten haastatteluiden tai kyselykaavakkeiden avulla saatuihin materiaaleihin. Hyvän näkökulman tähän tuo William Rathje, Arizonan yliopiston arkeologian emeritusprofessori, jonka Arizonan Tucsonissa 1973 aloitettu ja toteutettu, arkeologisen tutkimuksen klassikoksi noussut jäteprojekti osoitti eroja kerrotun ja kaivetun lähimenneisyyden välillä.

Jäteprojekti paljasti suuria eroja ihmisten kyselyissä sen välillä, mitä ihmiset kyselyissä arvioivat kulutuksestaan ja jätteistään ja mitä kaatopaikalla kaivettujen roskamäärien perusteella laskettiin kulutusmääriksi. Esimerkiksi ihmiset arvioivat kyselyjen perusteella alkoholin käytön 40-60\% todellista pienemmäksi, kun arvoa verrattiin jätteiden joukosta tavattuihin tyhjiin oluttölkkeihin (Rathje, William 2001, 64). Tämä ero ei ollut varsinaisesti yllätys, ja esimerkiksi markkinoitsijat tiesivät sen jo ennestään. Tosin ristiriidan havaitsemisen jälkeen haastatteluilla kerättyä tilastotietoa täydennettiin, jälleen kerran haastatteluilla (Rathje, William 2001, 64-65). Rathjen pettymys valitusta tutkimusmetodista lieveni kun tutkimuksissa verrattiin koko taloudesta vastaavan ilmoittamia kulutuslukuja yksittäisten kuluttajien lukuihin: ruoanlaittajat esimerkiksi ilmoittivat kulutuksen määrän suuremmaksi kuin yksittäiset syöjät. Ilmiö sai nimen "Good provider syndrome", Hyvän toimittajan syndrooma (käännökset minun). Samoin todettiin vastaavasti "Lean cuisine syndrome", Niukan ravinnon syndrooma: yksittäinen syöjä ilmoitti syövänsä huomattavasti todellista vähemmän (Rathje, William 2001, 65). Mitä alkoholin kulutukseen tulee, todettiin absolutistin antavan juojaa luotettavampia tietoja: "Surrogate Syndrom", Korvikesyndrooma (Rathje, William 2001, 65).

Tästä on kiusaus tehdä se johtopäätös, että arkeologeilla on todellisuudessa lopullinen tieto siitä, miten ihmiset oikeasti elävät. Tämä tieto ei kuitenkaan ole väistämättä relevantti eikä kerro tietyssä kulttuurissa elävästä ihmisestä oikeastaan mitään, mikäli hän ei pane sitä itse merkille. Jokainen voi laskea Helsingin Sanomissa hiilijalanjälkilaskurilla vaikutuksensa maapalloon kokonaisuutena ja lukea itseään järkyttävän totuuden vaikutuksestaan koralliriuttojen ripeään tuhoutumiseen, mutta miten todellisia arvot ovat? Entä kuka osaisi vetää yhtäläisyysmerkin yksittäisen roskiin heitetyn kahvinsuodattimen ja maapallon hiilidioksidipitoisuuksien välillä? Rathje on päätynyt ihmisten jätetutkimuksen perusteella kahteen tulkintaan: Joko ihmisillä ei ole käsitystä siitä, mitä he todellisuudessa kuluttavat ja heittävät pois, tai he huijaavat itseään (Rathje, William 2001, 67). Itsensä huijaamista on esimerkiksi ilmoittaa moottoriöljyn osuus pois heitetyssä kotitalouksien myrkyllisissä jätteissä (HHW, Household Hazardous Waste) oikeaa määrää huomattavasti suuremmaksi. Todellisuudessa sitä oli hyvin 


\section{Riku Kauhanen: Haastattelut arkeologiassa}

vähän, noin $23 \%$, mutta ilmoitusten mukaan se kattaisi tästä jätekategoriasta peräti $46 \%$. Rathjen mukaan kyseessä on machomaskuliinisuuden ilmentymä: miehet haluavat uskoa vaihtavansa omat moottoriöljynsä silloinkin, kun eivät todellisuudessa tee sitä (Rathje 2001, 66).

Toisaalta arkeologisin menetelmin kerätty idioottivarma data voi tulkinnoissa heittää harhaan. Mikä merkitys on sillä, että ihmiset leikkaavat kaksi kertaa useammin veitsellä eroteltavan läskin pois T-luupihveistään vuoden 1983 aikana? Ja miksi ostettiin entistä enemmän salamia, bolognaa, hot dogeja ja muita lihavalmisteita? 1983 National Academy of Science julkaisi raportin, jonka mukaan punaisen lihan rasva on rinta- ja suolistosyöpään sairastumisessa suuri riskitekijä. Ongelma onkin, että pihviliha korvattiiin entistä enemmän rasvaa sisältävillä lihatuotteilla, jolloin rasvan määrä ruokavaliossa pysyi ennallaan tai jopa kasvoi - ihmiset kun ymmärsivät sangen väärin punaisen lihan käsitteen. Ratjhen mukaan historiantuntijat toteaisivat mediaraportteja tutkittuaan ihmisten muuttaneen kulutustottumuksiaan, koska halusivat estää tauteja, mutta arkeologit arvelisivat syötyjen hot dogien ja salamien määrän kasvun perusteella ihmisten halunneen kasvattaa energiansaantiaan vaihtamalla rasvaisempiin ruokiin (Rathje 2001, 68).

Rathjen jäteprojekti osoitti eroja ihmisten ilmoittaman kulutuksen ja kvantitatiivisin menetelmin todettujen - arkeologisin kaivauksin löydettyjen ja mitattujen - määrien välillä. Suomessa tehtiin helsinkiläisten ja oululaisten arkeologien projektina tutkimusta Provinssirockissa 18.-20.6.2010. Projektissa kaivettiin koekuoppia festarialueelle, kartoitettiin RTS-GPS:llä roskien levintää ja haastateltiin festarivierailijoita kysymyskaavakkeiden avulla. Kaavakkeessa eroja hahmoteltiin festarialueelle kulkeutunutta omaisuutta seuraavin kysymyksin:

1. Mainitse viisi tärkeintä esinettä/tavaraa/tuotetta, jotka otit mukaan festareille?

2. A. Mainitse tärkein tähän paikkaan liittyvä muisto?

B. Voitko merkitä paikan karttaan/ kertoa sijainnin tarkemmin?

3. Mitä olet hukannut festareiden aikana? (Kuokkanen 25.1.2011; Kunnas ym. 2011, 28-29)

Kysely tehtiin samaan aikaan kun kenttätöitä projektista toteutettiin, mutta lopullisesti tiedot yhdistettiin toisiinsa vasta tutkimusten päätyttyä (Kuokkanen 25.1.2011), eikä esimerkiksi löytöjen avulla tehty täsmennettyjä kysymyksiä festarivierailijoille. Kysymysten perusteella pyrittiin kartoittamaan esinekulttuuria monin tavoin tärkeiden esineiden, "roskattujen" esineiden ja edelleen selkeästi kadotettujen esineiden välillä: viimeinen kategoria on merkittävä, sillä kadonnut kännykkä huomataan takuulla, mutta kadonnut Hesburger-kuitti jää todennäköisesti huomaamatta. Mistä osista reppunsa tai käsilaukkunsa sisältöä festarivierailija osaa kertoa? 'Tiivistäen, miten suuresta osasta omaa materiaalista kulttuuriaan, omaisuuttaan, ihminen on todella tietoinen? 


\section{LÄHIMENNEISYYS LASTAN PÄÄSSÄ JA KIELEN KÄRJESSÄ}

Tavallisesti kulttuuritutkijoiden tutkimustilana on kolmiomainen tilanne, jonka kärjet muodostuvat ajasta, paikasta ja tekijöistä toimintoineen, tai tiivistettynä "Joku tekee jossakin tietyssä paikassa tiettynä aikana jotakin". Arkeologeilla on paikka, jossa joku on tehnyt jotakin jonka seurauksena paikalle on jäänyt toiminnan jälkiä. Edellisessä luvussa oli esimerkkeinä jäteprojekteja, ja yleensä toiminnan jäljet ovatkin välittömästi toiminnan loputtua jätettä. Yleensä tarvitaan ajallinen intervalli ja unohtaminen, ennen kuin arkeologiaa edes harkitaan tutkimusmetodiksi.

Pohjoismaissa vuoden 2010 jäteprojektia ovat edeltäneet vuonna 2006 Ruotsissa $^{2}$, Herrestadissa suoritetut kaivaukset tanssipaikalla, joka oli käytössä 1939-1955. Tutkimuksissa haluttiin myös kuunnella ihmisten tarinoita ja muistoja paikasta sekä yhdistää ne löytöihin. Paikalliset olivat myös mukana koekuopituksessa. Samana vuonna Tanskassa Roskildessa kaivettiin ja tutkittiin muilla arkeologisilla menetelmillä vuodesta 1974 käytössä ollutta festivaalialuetta etnoarkeologian näkökulmasta, ilman että yleisöä olisi otettu osalliseksi kaivauksia: tuttu haluttiin nähdä tutkimuksissa vieraana (Helminen 2010).

Tällainen lähimenneisyyden arkeologia, contemporary archaeology, onkin hedelmällisin tapa saada lisätietoa arkeologisissa kaivauksissa tavatuista materiaaleista. Bristolin Stokecroftissa, Iso-Britanniassa kaivauksille otettiin, kuten Herrestadissa, paikallisia mukaan. Tosin kaivauskohteena oli paikka, joka oli ollut vuosisatojen ajan alkoholistien, narkkareiden ja muiden "laitapuolen kulkijoiden" suosima. Tällaisia profiileja vastaavat asukkaat otettiin mukaan projektiin; he kaivoivat arkeologien mukana paikalla ja osallistuivat löytöjen jatkokäsittelyyn yliopistolla. Jälkitöissä historiallisen ajan esinetuntija, arkeologian professori Mark Horton onnistui tunnistamaan 1700-luvun oluttuoppien sirpaleet, mutta äskettäin maahan päätyneen esineistön tunnistamisessa asiantuntijoita olivat laitapuolen kulkijat. Heroiininkäyttäjien esineistöstä tunnistettiin sosiaalipalveluiden jakama kuumennusastia, steri-cup, joka paikallisen ekspertin mukaan oli peräisin Bristolin ulkopuolelta, sillä Bristolin sosiaaliviranomaiset eivät niitä jakaneet (Stokecroft-video, Youtube).

Edelleen Stokecroft-tutkimuksen tehneestä Bristolin yliopistosta tuli aloite toisenlaiseen, moderniksi klassikoksi päätyneeseen arkeologian projektiin, Transit Vaniin. Ideana oli "kaivaa" Ironbridgen museon arkeologien ja museon huoltotoimen käyttämä pakettiauto. Projektiin ryhdyttiin kesällä 2006 (Bailey ym. 2009, 1). Auton osat saatiin purettua hyvin samaan tapaan kuin kaivausten stratigrafiassa ${ }^{3}$ tulevat eri maakerrokset ja anomaliat näkyviin. Auton eri osat tutkittiin hyvin tarkkaan ja löydöt käytettiin laajan asiantuntijakirjon kautta, aina biologeista oikeustieteen asiantuntijoihin. Muistitietoa, oral history, käytettiin myös apuna auton kaivauksissa paljastuneen historian tutkimisessa. Haastattelut tehtiin "kaivausalueen" lähellä niin että auto oli nähtävissä ja kosketusetäisyydellä (Bailey ym. 2009, 18). Tässä yhteydessä järjestettiin myös yksi joukkohaastattelu NAGTYn (National Association of Gifted and Talented Youngsters) vierailevalle lapsijoukolle, jotka ymmärsivät heti projektin arkeologisen filosofian merkityksen: heidän mielestään arkeologien auto arkeologisen kaivauskohteena täydensi arkeologisen tutkimuksen ympyrän (Bailey ym. 2009, 19). 


\section{Riku Kauhanen: Haastattelut arkeologiassa}

Yhden autoon läheisissä kosketuksissa olleen lähteen mukaan useat "juhliin liittyvät tapaukset" olivat syynä auton siirtoon arkeologeilta museon huoltopuolelle vuonna 1999. Todisteena näistä juhlista löydettiin autosta muun muassa pala samppanjalasia ja kultakonfettipaperia (Bailey ym. 2009, 12). Tämä juhla, jossa autoa oli käytetty alustana pomppulinnaan hyppäämiseen, oli ensimmäinen autoon liittyvä legendaariset mittasuhteet saanut tarina. Toinen kertomus koski auto-onnettomuutta, mistä löytyi todisteena vakuutuskorvaushakemus ja itse autosta litistynyt katto ja kokonaan vaihdettu sivuovi (Bailey ym. 2009, 18).

The Van oli poikkeuksellisen poikkitieteellinen ja moniulotteinen arkeologien projekti, ja se välitettiin nettisivujen ja tutkimuksista tehdyn lyhytfilmin The Van: Still in Transit avulla laajemmalle yleisölle. Vaikka tutkimuksen alussa esitettiin "Miksi?" kysymykseen vastaukseksi "Miksi ei?" (Bailey ym. 2009, 1) oltiin projektin arkeologien keskuudessa kiinnostuneita myös informanttien suhteesta itse projektiin, ei vain autoon. Niinpä anekdoottien, henkilökohtaisten muistojen ja auton herättämien muiden folkloristiikan tutkimusaloihin sopivien muistojen lisäksi informantteja pyydettiin kertomaan arvionsa tutkimuksen arkeologisesta relevanssista. Yllättävästi nuoremmat arkeologit suhtautuivat projektiin ja sen tarkoituksiin kriittisesti. Edelleen vastoin oletetusta vanhemmat arkeologit sen sijaan näkivät tutkimuksen kiinnostavat mahdollisuudet (Bailey ym. 2009, 18). Projektin edetessä seurattiin näiden mielipiteiden jakaumaa projektin alusta sen nettijulkaisujen alkamiseen ja jatkumiseen: projektin hyväksyttävyys kasvoi huomattavasti ehdottomasti kannattavien määrän kasvaessa 14\%:sta $23 \%$ :iin ja ehdottomien vastustajien määrän kaventuessa 47\%:sta 32\%:iin (Bailey ym. 2009, 17).

\section{Arkeologia haAstatteluna?}

Yli sata vuotta kihlakuntakertomusten jälkeen arkeologit Etelä-Amerikassa ryhtyivät sosiologisista lähtökohdista työhön, jonka vaiheet muistuttivat joiltakin osin suomalaisten ylioppilaiden tekemiä tutkimuksia. Samoihin aikoihin, kun muinaistieteellisen toimikunnan stipendeillä matkaavat muinaistutkijat kulkivat Suomessa keräämässä tarinoita, kirjoitti Emílio Goeldi Etelä-Amerikassa Rio Cunanin alueella näkemistään saappaanmuotoisista luolista ja muista mielenkiintoisista paikoista. David Green ja Lesley Fordred törmäsivät näihin liittyviin tarinoihin tutkimuksissaan vielä 1997 (Green ym. 2003, 372-373). Tämän seurauksena Brasilian Amazonjoen varrella, Amapán osavaltiossa, arkeologi Eduardo Nenves, sosiaaliantropologi Lesley Green sekä videokuvaaja David Green tekivät läheistä yhteistyötä paikallisen Palikur-heimon jäsenten kanssa vuodesta 2000 alkaen arkeologeille arvokkaiden tutkimusalueiden tutkimiseksi. Arkeologisten kenttätöiden yhteydessä paikallisille mitattiin ja kaivettiin malliksi muutamia koekuoppia ja heitä opetettiin tunnistamaan stratigrafiasta kulttuurikerroksia ja muita anomalioita. Näin heistä saatiin hyödyllisiä apulaistutkijoita projektiin, ja kolme palikuria osallistui kolmen viikon ajan varsinaiseen arkeologiseen kenttäkouluun Manauksessa kesällä 2001 (Green ym. 2003, 374-376). Amapán Palikur-alue valittiin arkeologisten tutkimusten kohteeksi, sillä siellä arvioitiin olevan mahdollisimman 


\section{Riku Kauhanen: Haastattelut arkeologiassa}

pieni katkos esikolonialististen intiaanien ja nykyisin elävien yhteisöjen välillä, jolloin arkeologisten kenttätöiden tuloksia saataisiin yhdistettyä entografiaan ja suulliseen traditioon (Green ym. 2003, 370) Vanhat, arvostetut viidakossa selviämisen taidot kuitenkin ovat alkaneet kadota, ja haastatellut palikurilaiset yhdistivät tämän suolan ja metallityökalujen käyttöön. Näillä seikoilla oli, kuten myöhemmin huomattiin, tärkeä osa heimon tapaa määrittää ja arvostaa itseään (Green ym. 2003, 372, 373).

Entografisista tutkimuksista vastaavien David Greenin ja Lesley Greenin tehtävänä oli kerätä vuonna 2000 kattava aineisto suullisesta historiasta ja tietoa potentiaalisista paikoista, sekä yrittää ymmärtää arkeologisille tutkimuksille mahdollisesti hyödyllisiä ja relevantteja paikallisia valtasuhteita ja tapoja toimia (Green ym. 2003, 373). Useita tarinankertojia haastateltiin Urucauá-joen varrelta seitsemästä kylästä, ja nämä esitykset videoitiin. Yhteensä saatiin videoitua 230 esitystä. Samoista tarinoista kerättiin erilaisia versioita vertailua varten. Tarinoissa toistuivat tietyt, etnohistoriallisesti tärkeät kohteet, joihin arkeologiset kenttätyöt seuraavaksi keskittyivät. Arkeologit päättivät kohteista yhteisissä kokouksissa paikallisten johtajien ja asukkaiden kanssa (Green ym. 2003, 374).

Yhteistyö paikallisten kanssa ei luonnistunut itsestään. Palikurilaisilla oli huoli paitsi päivittäisestä elannosta, omien maiden suojelusta ja pelosta menettää maansa brasilialaisille, myös lähestyvästä vuosituhannen vaihdosta mahdollisine maailmanloppuineen (Green ym. 2003, 377). Näille ihmisille oli hyvin vaikeaa selittää arkeologeille sinänsä tärkeiden vanhojen - mutta arvottomien - astiansirpaleiden ja menneisyyteen kohdistuvan kiinnostuksen merkitystä. Oli myös vaikeaa hahmottaa, mikä on heille kulttuuriperintöä. Siksi Greenien ja Nevesin oli kehitettävä paikallista väestöä kiinnostavia tutkimuskysymyksiä ja selitettävä samalla arkeologista kenttätyötä. Yritys käyttää museon kuvakirjaa apuna tulkittiin paikallisten keskuudessa todisteeksi aarteenmetsästyksestä (Green ym. 2003, 377). Tulkinta saatiin kuitenkin korjattua: paikallisten johtajien kanssa sorvattu kuvaus arkeologiasta "maahan jälkeenjätettyjen esineiden tutkimisesta", ikiska anavi wayk, muuttui puolentoista vuoden kuluttua 22 koulutetun kenttätyöläisen suussa muotoon ivegboha amekenegben gidukwankis: "esi-isien jälkien lukeminen"(Green ym. 2003, 377). Emic-etic asettelu toimii siis myös toisin päin, tutkijoiden on avattava omia tulkintojaan oman asiantuntemuksensa näkökulmasta paikallisille.

Haastatteluja tehtiin paitsi sopivien arkeologisten kenttätyökohteiden löytämiseksi, myös kenttätöiden aikana. Kenttätöiden ulkopuolella ihmiset toivat peltotöiden aikana maasta löytämiään vanhoja esineitä nyt tutkijoille sen sijaan, että olisivat tavalliseen tapaan heittäneet ne pois. Upeimpana esimerkkinä tuotiin vanha mela, jolle tutkija P. Barrére oli vuonna 1743 piirtänyt lähes täyden vastineen (Green ym. 2003, 374). Vanha mies Ixawet Labonté vei vuoden 2000 tarinoiden keräämisvaiheen aikana David Greenin suuren kivimuodostelman ääreen Karumna-vuoren lähettyville. Tämän asuinpaikan kerrottiin kuuluneen Kurumsuk-nimiselle jättiläisklaanille (Green ym. 2003, 378) (kiinnostava vertaus suomalaisten kihlakuntakertomuksissa esittämään jättiläisuskoon). Maassa lojui käsikirves eli migu. Kirveen löytyminen tallennettiin videolle ja siihen liittyvä dialogi käytiin seuraavasti: 


\section{Riku Kauhanen: Haastattelut arkeologiassa}

Ixawet: Migu... Vanhojen kirves (Old Ones). Se on Kurumsuk-kirves, koska se löytyi tällä. Löysitkö sen täältä?

David: Löysin sen tästä.

Ixawet: Sitten se on totta. Se on Kurumsuk-kirves. Se on hakkaamista varten... tah!

David: Etkö usko että Vanhat tekivät tämän?

Ixawet: Myös Vanhat tekivät samantapaisia kuin tämä. Toista tyyliä... kauniimpaa... kapeampaa. Tämä on kaunis. He pystyivät hakkaamaan suuria puita sillä (matkii puun hakkaamisesta ja kaatumisesta seuraavaa ääntä). Meillä jotka tulimme myöhemmin ei ole kestävyyttä siihen. $\mathrm{He}$ olivat hyvin vahvoja. He eivät syöneet suolaa (estää lihaa mädäntymästä). He eivät syöneet pippuria. He eivät syöneet mausteita. He söivät lihan raakana. Ah! He olivat hyvin sitkeitä. Joten he pystyivät hakkaamaan tällaisia puita...

Ixawet: ...Me, jotka tulemme myöhemmin, meillä ei ole mitään tällaisia. Tämä on kaunis kirves. Me, jotka tulimme myöhemmin, raivaamme peltomme metallilla. Kauan sitten se tehtiin jollakin tällaisella, kaadettiin puut ja raivattiin pellot. Me, jotka tulemme myöhemmin, meillä ei ole voimaa siihen. Me emme tiedä kuinka tehdä tällainen ... emme yhtikäs mitään. Me olemme unohtaneet taidot vuosien mittaan. Jos emme osta metallikirveitä emme saa tehtyä peltoa. Jos meillä ei ole machetea, emme saa hakattua puita. He tekivät jopa savikirveitä. He osasivat hakata puita niillä. Heillä oli macheteja, veitsiä, pannuja, kaikkea. Heillä oli ruukkuja. He osasivat laittaa ruokaa ruukuilla. Vanhat eivät ostaneet astioita kuten me. Silloin pystyi tekemään keramiikkaa, kauniita keramiikka-astioita. He tekivät darimwitseja (ruukkuja), tukutguseja (kaksikaulaisia ruukkuja), kaikenlaisia uurnia joihin saattoi laittaa kuolleen jäännökset kun hänet oli poltettu. He eivät tehneet (arkkuja) puusta. Me jotka tulimme myöhemmin teemme ne puusta kantaaksemme kuolleita... heillä oli uskallusta paahtaa ihminen (sekundaarisena hautaustapana). He paahtoivat ja laittoivat tugutkuun. Noin tämän kokoiseen. Iso ihminen, kuten sinä, saisi suuremman, astian jossa olisi kauniita merkkejä. He laittaisivat sinut sellaiseen kunnes tuhkasi täyttäisivät sen ja hautaisivat sinut sitten Kwapiin. Me, jotka tulemme myöhemmin, käytämme lautoja. Ja nauloja. Ymmärrätkö? He olivat vahvoja. Heillä oli paljon tietoa. Heillä oli paljon voimaa. Ymmärrätkö? (Green ym. 2003, 378-379, suomennos valituista katkelmista minun)

Yhden ainoan kivikirveen nähtyään vanhus muisti paljon menneestä ja osasi kertoa paitsi muista esineistä, myös kunnioitettavista arvoista jotka menneisyyden ihmisiin liitetään ja tekijöistä, joiden katoamisen katsotaan heikentäneen tämän päivän Palikureja: mausteista ja metallista. Greenin mukaan haastattelu osoittaa Palikurien kulttuuriperinnön liittyvän menneisyyden ihmisten taitojen, sitkeyden, vahvuuden ja urheuden nostalgiaan, ei niinkään jälkeen jääneeseen materiaalikulttuuriin (Green ym. 2003, 379). 


\section{Riku Kauhanen: Haastattelut arkeologiassa}

Arkeologisten kaivausten tulosten yhdistäminen paikallisiin narratiiveihin ei kuitenkaan ole niin yksiselitteistä kuin voisi olettaa. Kiinnostavimpana tutkituista paikoista Neves ja muut kävivät Ivegepketissä, paikassa jonka merkiksi kuvailtiin suuri simpukoista koostuva kumpu, tunkio. Paikka tunnetaan palikurien keskuudessa suuren Waramwi-käärmeen kotina, Waramwi-givin. Waramwi oli legendan olento, jonka Palikurit päihittivät taistelussa viidakon voimia vastaan. Pitkän etsinnän jälkeen kumpu löydettiin, sen koko mitattiin ja kotiloiden jäänteitä kerättiin näytteiksi jatkotutkimuksiin. Kylässä tutkijoiden paluu herätti suurta huomiota, sillä Waramwi-givin löytyminen oli suuri ihmetyksen aihe. Monet tulivat tutkijoiden taloon pelkästään nähdäkseen kummulta tuodut simpukat (Green ym. 2003, 388). Joillekin tämä vahvisti legendan todeksi, mutta toisenlaisia ääniä kuultiin kentällä mukana olleiden keskuudesta, kuten Lesley Greenin muistikirjan merkinnästä käy ilmi:

Palasin talolle ja tapasin Nenelin ja Ivanildon hartaassa keskustelussa. En ymmärtänyt täysin mitä he sanoivat mutta he puhuivat Waramwista ja esi-isistään ja heidän tarinoistaan. Keskustelun henki tyrmistystä. Nenel huokaisi "Yuma Waramwi" (Ei Waramwia). Hänen äänensävystään kuulsi läpi keskustelun lopputulos. Kysyin häneltä 'Uskotko todella ettei Waramwia ole?".

"Ei ole". Kysyin häneltä, miksi ei ole, ja Ivanildo alkoi selittämään. Kun hän oli edellisenä päivänä käynyt kummulla eikä nähnyt siellä koloa (reittiä tuonpuoleiseen) hän oli erittäin pettynyt. Kummulla ei ollut lainkaan Waramwin koloa. Joten miten Waramwi voisi olla totta? "Se on vain myytti" hän sanoi ja jatkoi "kuten tarinat siitä että valkoiset löysivät Brasilian 500 vuotta sitten". Joten vanhusten kertomat tarinat olivat pelkkiä uskomuksia, ilman totuuden pohjaa. (Green ym. 2003, 388)

Kirjoittajat näkevät tässä paradoksin arkeologien yrittäessä tutkia tietyn paikan kulttuurista merkitystä ja kerätessä tulkintoja siitä. Kuitenkin sama tutkimus voi muuttaa käsityksiä monitulkintaisista paikoista ja jopa murskata näitä tulkintoja (Green ym. 2003, 389). Maanäytteillä ja laboratoriotutkimuksilla on oma merkityksensä omassa kontekstissaan, mutta Green, Green ja Neves painottavat, että kulttuuriperinnön suojelussa on kyse merkitysten suojelemisesta. Mikäli paikalliset halutaan mukaan suojelemaan ja arvostamaan historiallisesti arvokkaita paikkoja, tulisi kirjoittajien mukaan antaa enemmän painoarvoa haastatteluilla ja muilla etnografisilla menetelmillä kerätyille etnohistorioille, paikallisille versioille menneisyydestä, ei niinkään arkeologiselle, laajemmin hyväksytylle materiaaliseen kulttuuriin perustuvalle kronologialle (Green ym. 2003, 389).

Tutkimukset Palikur-heimolaisten keskuudessa herättävät kysymyksen, voimmeko suojella kulttuuriperintöä mikäli muutamme tutkimuksellamme sen merkitystä? Tämä pätee yhtä hyvin lähimenneisyyteen kuin kivikautiseen asuinpaikkaankin. Toisaalta, onko yksinomaan arkeologien syytä mikäli väestön suhde esi-isiinsä ja näiden jättämiin materiaalisen kulttuurin jälkiin, muinaisjäännöksiin, muuttuu suuntaan tai toiseen? 


\section{Riku Kauhanen: Haastattelut arkeologiassa}

Edelleen, eikö kivikautisten työkalujen käyttö ukonvaajoina, maagisina esineinä, ole omalla tavallaan luonteva osa niiden elinkaarta? Annamme suojelun ylettyä ajallisesti yhä lähempiin kohteisiin, mutta pitäisikö niiden kohdata ajan testi, ja antaa historian ja muistojen kertyä - ja kadota- ilman keinotekoisia tieteellisiä apparaatteja?

\section{Arkeologian haAstattelujen taustoista}

Palikurilaisten parissa kenttätöitä tehneellä Leslie Greenillä oli Journal of Social Archaeologyn artikkelin mukaan kulttuuriantropologin koulutus (Green ym. 2003, 366). Muissa yhteyksissä näitä koulutustaustoja ei valitettavasti tuoda ilmi. Kihlakuntakertomuksissa ei voi vielä olettaa kirjoittajien reflektoivan omaa taustaansa, mutta esimerkiksi Transit Vanin tai Stokecroftin yhteydessä ei haastattelutekniikoista tai esitetyistä kysymyksistä kerrota tarkemmin. Ylipäätään julkaisujen perusteella on epävarmaa, oliko haastatteluissa edes minkäänlaista runkoa käytössä. Samoin William Rathjen jäteprojektin taustana oli pitkälti sosiologisten haastattelujen tutkimustulosten ja arkeologisten kaivausten tulosten vertailun kontrasti.

Sain oululaiselta Tiina Kuokkaselta pyynnöstäni Provinssirockissa käytetyn haastattelulomakkeen, jonka haastattelujen taustalla hän kertoi olevan sosiologian opintojen (Kuokkanen 25.1.2011). Selkeästi haastatteluiksi tarkoitetut informanttien kuulemiset ovat suhteellisen harvinainen osa arkeologien kenttätöitä, mutta esimerkiksi Koljonvirran taistelupaikan kenttätöiden yhteydessä vuonna 2005 haastateltiin muutamia paikallisia aikaisempien löytöjen ja löytyalueiden kartoittamiseksi (Poutiainen 2005, 8 ja 32). Sen sijaan haastatteluja on tehty joidenkin opinnäytteiden yhteydessä, Turussa esimerkiksi Hannele Partasen proseminaarissa "Arkeologian kiinnostavuudesta ja tavoitettavuudesta Turussa vuonna 2005 tehty kyselytutkimus" tai filosofi Saara Peuran sivuaineproseminaarin "Etiikkaa arkeologeille? Nykytilanne ja kehitystarpeita etiikan opetuksessa arkeologiassa" yhteydessä. Oulussa Sanna Marin, joka myös teki haastattelut Koljonvirralla, käytti kyselyjä lähdeaineistona gradussaan "Koljonvirran sotahistoriallinen alue ja sen merkitys paikallisidentiteetille" ja Helsingissä Hanna Kaivonurmi teki 2008 gradun "Mitä kivet kertovat? Museoammattilaisten haastattelut esihistorian näyttelystä viestinnän välineenä”. Kyselytutkimuksilla on vahva yhteys arkeologian käyttöön pedagogiikassa.

Opinnäytteissä kysymykset, kyselyt ja haastattelut ovat lähes poikkeuksetta mukana liitteinä. Kysymykset tai haastattelutilanteet kirjoitetaan kuitenkin harvoin artikkeleissa auki jolloin riskinä on, että tällaisissa projekteissa turvaudutaan haastatteluaineistoon ainoastaan silloin, kun se tukee tiettyä tulkintaa tai on riittävän "mediaseksikästä". Arkeologisissa artikkeleissa tulisi huomioida haastattelut muunakin kuin lisämausteena. Tyystin ilmoittamatta jää, millaiselta taustalta kysymykset laaditaan: sosiologi, kulttuuriantropologi, kansatieteilijä tai uskontotieteilijä laativat erilaisia kysymyksiä ja kiinnittävät haastatteluissa huomiota eri asioihin. Taustat esille tuomalla pystyttäisiin arvioimaan, mistä osa-alueista voisi vielä toisesta näkökulmasta tehdä jatkotutkimuksia. Samalla haastatteluja kriittisesti pohtimalla saataisiin jaettua kokemuksia ja toimivia haastattelutekniikoita kollegojen kanssa. 


\section{LOPPUHUOMIOITA JA AJATUKSIA}

Kuten edellä kirjoitetusta käy ilmi, paikallisia informantteja, kyselyjä ja haastatteluja on käytetty arkeologisten kenttätöiden ja perustutkimusten yhteydessä useaan otteeseen ja eri tavoin. Jo muinaistieteellisen profession alkuaikoina Suomessa esitettiin perustutkimuksen yhteydessä kysymyksiä paikallisille ja problematisoitiin informanttien tietoja ja näiden suhteita menneisyyteen. Haastattelut ovat kokeneet suoranaisen renesanssin 1980-luvulta alkaen yleisöarkeologian (public archaeology) ja lähimenneisyyden arkeologian nousun yhteydessä.

Haastattelut eivät kuitenkaan ole pelkästään keino saada lisää tietoa tutkimusaiheesta tai yleisön suhteesta siihen. Informantit voidaan ottaa mukaan itse tutkimusprosessiin tai näitä voidaan haastatella tutkimuskohteen lähettyvillä, jolloin saadaan taas erilainen ote ja asiantuntemus tutkimusaiheeseen. Provinssirockissa kyselyt ja arkeologiset kenttätyöt tehtiin erillään, Transit Vanissa haastattelut tehtiin tutkittavan pakettiauton lähellä, Stokecroftissa paikalliset olivat mukana kaivamassa ja jälkitöissä tutkimassa. Amatsonissa paikallisille ja näiden tulkinnoille annettiin keskeinen rooli arkeologisen tulkinnan jäädessä kapeammaksi. Kaikesta tästä voidaan laatia seuraavanlainen karkea runko tuleviin haastatteluihin joissa suunnitellaan, mikä rooli arkeologisten kaivausten ja informanttien eri elementeillä on haastatteluissa:

Taulukko 1: Arkeologisen tutkimuksen informantit, aineistot ja näiden rooli haastatteluja silmälläpitäen.

\begin{tabular}{|c|c|c|}
\hline & Rooli tutkimuksissa & \\
\hline $\begin{array}{l}\text { Löytöjen käyttö tutkimuk- } \\
\text { sissa ja haastatteluissa: }\end{array}$ & $\begin{array}{l}\text { Yhdessä (kaivaukset julkiset, haas- } \\
\text { tattelut tehdään samanaikaisesti } \\
\text { samassa paikassa) }\end{array}$ & $\begin{array}{l}\text { Erillään (haastattelut yhdis- } \\
\text { tetään tutkimustuloksiin } \\
\text { myöhemmin) }\end{array}$ \\
\hline Informanttien käyttö: & $\begin{array}{l}\text { Mukana (kaivajia, tutkimusavus- } \\
\text { tajia)* }\end{array}$ & Erillään (vain haastateltavia) \\
\hline Informanttien rooli: & Vahva (tulkitsija) & Heikko (tiedonantaja) \\
\hline
\end{tabular}

*monesti tällöin halutaan myös vaikuttaa informanttien kulttuuriperintötietoisuuteen ja saada tietoa suhteesta siihen.

Provinssirockissa löydöt ja informantit olivat erillään, ja informanttien rooli oli kyselykaavakkeen täyttöä lukuun ottamatta heikko. Nämä tiedot yhdistettiin myöhemmin kaivaustuloksiin. Transit Vanissa informantit näkivät kaivausten sen hetkisen vaiheen, mutta olivat muuten erillään. Heidän roolinsa oli tulla kuulluiksi ja tasaveroisiksi tulkitsijoiksi. Palikurissa taas kaikki elementit olivat vahvasti läsnä haastatteluissa. William Rathjen huomautus ihmisten suhteesta omaan jätetietouteensa tulee muistaa haastatteluja suunnitellessa. Ihmisen muisti on tulkitsija, ei faktojen säilöjä. Ihmiset voivat erillään arkeologisista tutkimuksista antaa huomattavasti luotettavampaa tietoa kuin nähdessään esineet ja paikat: tuskin kukaan tunnustaa Provinssirockissa kylväneensä karkkipapereita parkkipaikalle, vielä harvempi osaa mainita määrää, mutta 


\section{Riku Kauhanen: Haastattelut arkeologiassa}

saattaa yhdistää tämällaisen käytöksen inhoamansa bändin T-paitaa pitävään. Toisaalta nähdessään esimerkiksi Hesburgerin paperipussin festarivieras voi muistaa käyneensä päivien yhteydessä syömässä purilaispaikassa, vaikka tämä olisikin tapahtunut samassa tapahtumassa - vuotta aikaisemmin.

Kysymykseen viidestä tärkeimmästä Provinssirockiin mukaan otetusta esineestä saattaa vaikuttaa sää: sateella listatuksi tulee sateenvarjo, aurinkoisella vesipullo tai aurinkolasit. Vaikka trendinä on korostaa paikallisten asiantuntemusta ja näiden tulkintojen oikeutta tulla kuulluiksi, on otettava huomioon, miten itse tutkimus muuttaa näitä tulkintoja. Edellä laatimani taulukko 1 listaa ainakin kolme tekijää, joiden läsnäolo voi vaikuttaa (paikallisten anomalioiden, kuten sääolojen lisäksi) haastatteluissa saataviin vastauksiin, siis tarinoihin, joita haastateltava odottaa haastattelijan haluavan kuulla. Olisiko Transit Vaniin liittyvä tarina pahasta kolarista jäänyt kertomatta, mikäli vahinkoa kärsineet osat olisi juuri poistettu autosta ja ne olisivat olleet hasstatteluhetkellä väärin päin haastateltavaan nähden? Mikäli onnettomuuksia olisi ollut kaksi, ja eri kolareissa vahingoittuneet osat olisivat olleet näkyvillä samanaikaisesti, olisiko haastateltava yhdistänyt nämä molemmat yhteen ja samaan tapahtumaan? Vaikuttaa siltä, että haastattelujen käytön mahdollisesti lisääntyessä arkeologien aineopintoihin tulee liittää muistitiedon peruskurssi.

Haastatteluilla on arkeologiassa paljon mahdollisuuksia: niiden käytön avoimuutta ja toteutusta tulisi kuitenkin tulevia tutkijoita ja menetelmästä kiinnostuneita ajatellen kirjoittaa enemmän auki julkaisuissa. Luonnollisesti arkeologien painopiste on materiaalisessa kulttuurissa, eikä julkaisuilta voi edellyttää tasapainoista osuutta tukeville tieteille, elleivät nämä ole olleet tutkimuksessa poikkeuksellisessa roolissa. Esimerkiksi hiilikaivoslakkolaisten leirialueen arkeologista tutkimusta käsittelevä teos The Archaeology of Class War: The Colorado Coalfield Strike of 1913-1914 (Karin Larkin \& Randall H. McGuire: 1999) omistaa kokonaisen artikkelin muistitiedolle ja sen variaatoille (s. 311-330). Kysymysten relevanttius tutkimusaineistoon käy usein ilmi, mutta tutkijoiden relevanttius esitettyihin kysymyksiin nähden ei. Tätä kaikkea tulisi vastaisuudessa pohtia, sillä arkeologi saa vastauksia muualtakin kuin koekuopan pohjalta.

Arkeologeille relevantit informantit eivät sittenkään ole kaikki kuolleita.

\section{KirjallisuUs}

BAILEY, GREG \& NEWLAND, CASSIE \& NILSSON, ANNA \& SCHOFIELD, JOHN 2009: Transit, Transition: Excavating J641 VUJ. Cambridge Archaeological Journal. VOL 19, No: 1, 2009. Cambridge University Press.

BURSTRÖM, MATS 2007: Samtidsarkeologi. Introduktion till ett forskningsfält. Pozkal.

GREEN, LESLEY FORDRED \& GREEN, DAVID r. \& NEVES, EDUARDO GOÉS 2003: Indigenous knowledge and archaeological science. Journal of Social Archaeology. Volume 3, Number 3, October 2003. Sage publications.

HARRIS, EDWARD. 1989 (1979): Principles of archaeological stratigraphy. Second edition. Academic Press, London. 


\section{Riku Kauhanen: Haastattelut arkeologiassa}

KILLINEN, KUST. 1889: Luetteloja Suomen muinaisjäännöksistä XVI. Sortavalan kihlakunta. Muinaisjäännöksiä ja -muistoja Sortavalan kihlakunnassa. Suomen Muinaismuisto-yhdistys. Helsinki.

KUNNAS, OLLI \& KUOKKANEN, TIINA \& MÖNKKÖNEN, RIKU \& PERTTOLA, WESA 2011: Sinusta jää jälki. Arkeologit tutkimassa Provinssirockin festivaalialuetta. Muinaistutkija 1/2011. 21-34.

LARKIN, KARIN \& MCGUIRE, RANDALL H. 1999: The Archaeology of Class War: The Colorado Coalfield Strike of 1913-1914. University Press of Colorado.

PELKONEN ANTERO 1902: Luetteloja Suomen muinaisjäännöksistä. XXIII. Rantasalmen kiblakunta. Suomen Muinaismuistoyhdistys. Helsinki.

RATHJE, WILLIAM 2001: Integrated archaeology: a garbage paradigm. Teoksessa Archaeologies of the Contemporary Past. - Victor Buchli \& Gavin Lucas (toim.). London.

TAKALA, ESA EETU 1896: Luetteloja Suomen muinaisjäännöksistä. XXII. Pietarsaaren kiblakunta. Muinaismuistoja Pietarsaaren kihlakunnan suomalaisesta osasta. Suomen Muinaismuisto-yhdistys. Helsinki.

WALLIN, VÄINÖ 1892: Kertomus Hollolan kiblakunnan muinaisjäännöksistä. Luetteloja Suomen muinaisjäännöksistä. XVIII. Hollolan kihlakunta. Helsinki.

\section{Julkaisemattomat lähteet}

BLOMQVIST, A. R., Kiinteät muinaisjäännökset Kymin kihlakunnassa. Käsikirjoitus Museoviraston arkeologian osaston arkisto. Helsinki.

KAIVONURMI, HANNA 2008: Mitä kivet kertovat? Museoammattilaisten haastattelut esihistorian näyttelystä viestinnän välineenä. Pro gradu -tutkielma. Helsingin yliopisto, arkeologia.

MARIN, SANNA 2005: Koljonvirran sotahistoriallinen alue ja sen merkitys paikallisidentiteetille. Pro gradu -tutkielma. Oulun yliopisto, yleinen arkeologia.

PAKKALA, E. W. 1902: Luettelo Pernajan kihlakunnan suomalaisten pitäjien muinaismuistoista. I vihko. Käsikirjoitus. Museoviraston arkeologian osaston arkisto. Helsinki.

PARTANEN, HANNELE 2005: Arkeologian kiinnostavuudesta ja tavoitettavuudesta Turussa vuonna 2005 tehty kyselytutkimus. Proseminaaritutkielma. Turun yliopisto, arkeologia.

PEURA, SANNA 2007: Etiikkaa arkeologeille? Nykytilanne ja kehitystarpeita etiikan opetuksessa arkeologiassa. Proseminaaritutkielma. Turun yliopisto, arkeologia.

POUTIAINEN, HANNU 2005: Iisalmi Koljonvirta. Taistelualueen arkeologinen tutkimus.

Raportti. Koljonvirta - Historiaa ja yrittäjyyttä. Interreg III A Karjala-hanke. Mikroliitti Oy. Rakennushistorian osasto, Museovirasto. Helsinki.

\section{Internetlähteet}

HELMINEN, MIKKO 2010: Lähimenneisyyden ja nykyajan tutkimuksesta arkeologiassa. [online] < http://fielddiary.wordpress.com/2010/02/28/lahimenneisyydenja-nykyajan-arkeologisen- tutkimuksen-teoreettisia-nakokulmia/> [16.2.2011.] 
MUHONEN, TIMO 2006: Kolme ajallista näkökulmaa ukonvaajoihin. Kivikauden kiviesineet myöhempien aikojen kuriositeetteina. Kuriositeettikabinetti 3/2006 [online]. <http://www.kuriositeettikabi.net/numero3/Ukonvaajat.pdf> ]16.3.2011.]

"Stokes croft excavation" video Youtubessa [online]. <http://www.youtube.com/ watch?v $=8 \mathrm{GbiQrbp33s>} \mathrm{[27.1.2011.]}$

\section{Muut lähteet}

KUOKKANEN, TIINA. Sähköpostitse 25.1.2011 saatu tiedonanto.

\section{VIITTEET}

1Ukonvaaja on esihistoriallinen, yleensä symmetrinen kiviesine johon liitetään maagisia uskomuksia esimerkiksi suojelevan taikuuden merkeissä. Katso aiheesta enemmän Muhonen, Timo: Kolme ajallista näkökulmaa ukonvaajoihin. Kivikauden kiviesineet myöhempien aikojen kuriositeetteina. Kuriositeettikabinetti 3/2006 osoitteessa : http://www.kuriositeettikabi.net/numero3/Ukonvaajat.pdf

2Ruotsissa lähimenneisyyden arkeologiasta käytetään nimitystä samtidsarkeologi, kst. esim. Burström, Mats: 2007. Samtidsarkeologi. Introduktion till ett forskningsfält. Pozkal.

3Stratigrafia on geologinen termi, joka tarkoittaa geologisten muodostumien kertymistä ja järjestymistä niin, että alemmat kerrokset ovat ylempiä vanhempia jolloin niiden ajallinen suhde toisiinsa on tutkimuksen kohteena. Arkeologiassa stratigrafialla erotetaan kulttuurikerroksia (ihmisen toiminnan seurauksena syntyneitä maakerroksia) ja tutkitaan niiden suhteita toisiinsa samoin periaattein. Suhteellinen ikä ei kuitenkaan tarkoita kerroksen absoluuttista ikää, vaikka se voidaankin esineiden, radiohiiliajoitusten yms. perusteella todentaa. Ks. tarkemmin Harris, Edward. 1989. Principles of archaeological stratigraphy.

\section{Riku Kauhanen on HuK ja arkeologian pääaineopiskelija Turun yliopistossa}

